\title{
CATATAN TEMBANG GUBAHAN PURNOMO
}

\author{
Nur Laili Ilma Resti Fauziah \\ Universitas Nahdlatul Ulama Sidoarjo
}

\section{PENGANTAR}

Puisi merupakan koleksi literasi melibatkan emosi dan ide (A Research Guide, 2019). Puisi adalah genre sastra yang ditandai dengan menjadi manifestasi yang paling halus, melalui kata, dari perasaan, emosi dan refleksi yang dapat diekspresikan oleh manusia di sekitar keindahan, cinta, hidup atau mati. Dengan demikian, dapat disusun dalam kedua ayat dan prosa. Kata puisi berasal dari puisi Latin, dan pada gilirannya berasal dari bahasa Yunani íónбıs ( puisi ), yang berarti 'melakukan', 'mewujudkan'. Dahulu, puisi ditulis hanya dalam ayat-ayat, diatur oleh seperangkat aturan tentang komposisi yang disebut metrik. Namun, puisi modern dicirikan oleh dominasi ayat bebas, di mana penulis memiliki kebebasan total untuk mengatur dan mengatur ayat-ayat dalam teks, dan menemukan ritme mereka sendiri, tanpa ikatan sajak atau metrik (Significados, 2018). 
Puisi pada dasarnya memberi manfaat dan guna dengan dapat mengatakan hampir secara eksklusif, ekspresi emosi dan perasaan, di mana bentuk literatur yang diteliti dan diuraikan memberikan nilai-nilai komunikatif yang lebih luas dan lebih dalam. Ini berarti bahwa pada abad terakhir puisi telah membatasi fungsi dan realisasinya terhadap lirik, sedemikian rupa sehingga saat ini istilah lirik akhirnya mengidentifikasikan dirinya dengan puisi itu sendiri dan tidak lagi menjadi salah satu bentuk kreativitas dalam syair. Puisi dalam sejarahnya telah kehilangan banyak kekayaan kreatif dan ekspresifnya yang beragam, jadi untuk memahami puisi secara mendalam, mungkin tepat untuk kembali ke asalnya (Giangoia, 2006).

\section{SI PENYAIR}

Penyair bernama lengkap Agung Purnomo dan tumbuh di Sidoarjo. Beliau merupakan salah satu seorang dosen di Indonesia. Berikut tulisan syair beliau telah disebarkan secara luas melalui penerbit nasional, yaitu: STIEBA Madura Press, ITB Press, dan UNUSIDA Press. 


\section{Tabel 1. Tembang Karangan Agung Purnomo}

\begin{tabular}{|c|c|c|c|c|c|c|}
\hline No & $\begin{array}{l}\text { Judul } \\
\text { Puisi }\end{array}$ & Penulis & $\begin{array}{l}\text { Jenis } \\
\text { puisi }\end{array}$ & $\begin{array}{l}\text { Judul } \\
\text { buku }\end{array}$ & Penerbit & Tahun \\
\hline 1 & Berpulang & $\begin{array}{r}\text { Agung } \\
\text { Purnomo }\end{array}$ & Puisi epitaf & $\begin{array}{r}\text { Syair } \\
\text { Nimala }\end{array}$ & $\begin{array}{r}\text { STIEBA } \\
\text { Madura } \\
\text { Press }\end{array}$ & 2019 \\
\hline 2 & $\begin{array}{r}\text { Bapak } \\
\text { Samsuri } \\
\end{array}$ & $\begin{array}{r}\text { Agung } \\
\text { Purnomo, } \\
\text { Nur } \\
\text { Asitah } \\
\end{array}$ & $\begin{array}{r}\text { Puisi } \\
\text { Clerihew }\end{array}$ & $\begin{array}{r}\text { Dhalubang } \\
\text { Marta }\end{array}$ & $\begin{array}{r}\text { STIEBA } \\
\text { Madura } \\
\text { Press }\end{array}$ & 2019 \\
\hline 3 & Dua Kaki & $\begin{array}{r}\text { Agung } \\
\text { Purnomo }\end{array}$ & $\begin{array}{r}\text { Puisi } \\
\text { Bebas }\end{array}$ & $\begin{array}{c}\text { Kidung } \\
\text { Nawala } \\
\text { (Jilid 2) }\end{array}$ & $\begin{array}{r}\text { UNUSIDA } \\
\text { Press } \\
\end{array}$ & 2018 \\
\hline 4 & Tangisnya & $\begin{array}{r}\text { Agung } \\
\text { Purnomo, } \\
\text { Nur } \\
\text { Asitah } \\
\end{array}$ & $\begin{array}{r}\text { Puisi } \\
\text { Naratif } \\
\end{array}$ & $\begin{array}{r}\text { Bhumi } \\
\text { Bawera } \\
\end{array}$ & $\begin{array}{r}\text { STIEBA } \\
\text { Madura } \\
\text { Press } \\
\end{array}$ & 2019 \\
\hline 5 & Pandai & $\begin{array}{r}\text { Agung } \\
\text { Purnomo, } \\
\text { Nur } \\
\text { Asitah } \\
\end{array}$ & $\begin{array}{r}\text { Puisi } \\
\text { Riddle }\end{array}$ & $\begin{array}{r}\text { Tolesan } \\
\text { Aditi } \\
\end{array}$ & $\begin{array}{r}\text { STIEBA } \\
\text { Madura } \\
\text { Press } \\
\end{array}$ & 2019 \\
\hline 6 & $\begin{array}{r}\text { Sepekan } \\
\text { Awal } \\
\text { Tanpamu } \\
\end{array}$ & $\begin{array}{r}\text { Agung } \\
\text { Purnomo, } \\
\text { Nur } \\
\text { Asitah } \\
\end{array}$ & $\begin{array}{r}\text { Puisi } \\
\text { bersekuen }\end{array}$ & $\begin{array}{r}\text { Arebhan } \\
\text { Helai } \\
\end{array}$ & $\begin{array}{r}\text { STIEBA } \\
\text { Madura } \\
\text { Press } \\
\end{array}$ & 2019 \\
\hline 7 & Cantik & $\begin{array}{r}\text { Agung } \\
\text { Purnomo, } \\
\text { Nur } \\
\text { Asitah } \\
\end{array}$ & $\begin{array}{r}\text { Puisi } \\
\text { Jenaka } \\
\text { Limerick }\end{array}$ & $\begin{array}{r}\text { Lembhar } \\
\text { Jiwana }\end{array}$ & $\begin{array}{r}\text { STIEBA } \\
\text { Madura } \\
\text { Press }\end{array}$ & 2019 \\
\hline 8 & \#CH1 & $\begin{array}{r}\text { Agung } \\
\text { Purnomo }\end{array}$ & $\begin{array}{r}\text { Puisi } \\
\text { Bebas }\end{array}$ & $\begin{array}{c}\text { Kidung } \\
\text { Nawala } \\
\text { (Jilid 1) }\end{array}$ & $\begin{array}{r}\text { UNUSIDA } \\
\text { Press } \\
\end{array}$ & 2018 \\
\hline 9 & Menyala & $\begin{array}{r}\text { Agung } \\
\text { Purnomo }\end{array}$ & $\begin{array}{r}\text { Puisi } \\
\text { Haiku }\end{array}$ & $\begin{array}{r}\text { Tenta } \\
\text { Kimaya } \\
\end{array}$ & $\begin{array}{r}\text { STIEBA } \\
\text { Madura } \\
\text { Press } \\
\end{array}$ & 2019 \\
\hline 10 & Kita & $\begin{array}{r}\text { Agung } \\
\text { Purnomo, } \\
\text { Elsa } \\
\text { Rosyidah } \\
\end{array}$ & $\begin{array}{r}\text { Puisi } \\
\text { Bebas }\end{array}$ & $\begin{array}{r}\text { Suweda } \\
\text { Ate }\end{array}$ & $\begin{array}{r}\text { STIEBA } \\
\text { Madura } \\
\text { Press }\end{array}$ & 2019 \\
\hline 11 & $\begin{array}{r}\text { Rindu di } \\
\text { Ubun- } \\
\text { Ubun }\end{array}$ & $\begin{array}{r}\text { Agung } \\
\text { Purnomo }\end{array}$ & $\begin{array}{r}\text { Puisi } \\
\text { Bebas }\end{array}$ & $\begin{array}{r}\text { Rassana } \\
\text { Jlantir } \\
\end{array}$ & $\begin{array}{r}\text { STIEBA } \\
\text { Madura } \\
\text { Press }\end{array}$ & 2019 \\
\hline
\end{tabular}




\section{CATATAN MENARIK}

Inilah tajuk-tajuk syair gubahan Agung Purnomo yakni: rindu di ubun-ubun (Purnomo, 2019c), sepekan awal tanpamu (Purnomo \& Asitah, 2019d), \#CH1 (Purnomo, 2018a), cantik (Purnomo \& Asitah, 2019b), berpulang (Purnomo, 2019a), dua kaki (Purnomo, 2018b), bapak Samsuri (Purnomo \& Asitah, 2019a), menyala (Purnomo, 2019b), tangisnya (Purnomo \& Asitah, 2019e), pandai (Purnomo \& Asitah, 2019c), dan kita (Purnomo \& Rosyidah, 2019).

Agung Purnomo menulis sebelas puisi dengan gaya epitaf, clerihew, bebas, riddle, bersekuen, jenaka limerik dan haiku. Puisi diterbikan pada tahun 2018 dan tahun 2019. Puisi enak dibaca dan mudah dipahami oleh pembaca. 


\section{REFERENCES}

A Research Guide. (2019). Poetry Structure and Its Usage in Poems. Retrieved June 25, 2019, from https://www.aresearchguide.com/poetrystructure.html

Giangoia, R. E. (2006). La funzione della poesia nel mondo antico. Retrieved June 23, 2019, from https://bombacarta.com/2006/08/09/la-funzionedella-poesia-nel-mondo-antico/

Purnomo, A. (2018a). \#CH1. In Kidung Nawala (Jilid 1). Sidoarjo: UNUSIDA Press.

Purnomo, A. (2018b). Dua Kaki. In Kidung Nawala (Jilid 2). Sidoarjo: UNUSIDA Press.

Purnomo, A. (2019a). Berpulang. In Syair Nimala. Sumenep: STIEBA Madura Press.

Purnomo, A. (2019b). Menyala. In Tenta Kimaya.

Sumenep: STIEBA Madura Press.

Purnomo, A. (2019c). Rindu di Ubun-Ubun. In

Rassana Jlantir. Sumenep: STIEBA Madura Press.

Purnomo, A., \& Asitah, N. (2019a). Bapak Samsuri.

In Dhalubang Marta. Sumenep: STIEBA Madura Press.

Purnomo, A., \& Asitah, N. (2019b). Cantik. In Lembhar Jiwana. Sumenep: STIEBA Madura Press.

Purnomo, A., \& Asitah, N. (2019c). Pandai. In Tolesan Aditi. Sumenep: STIEBA Madura Press. Purnomo, A., \& Asitah, N. (2019d). Sepekan Awal Tanpamu. In Arebhan Helai. Sumenep: STIEBA Madura Press. 
Purnomo, A., \& Asitah, N. (2019e). Tangisnya. In Bhumi Bawera. Sumenep: STIEBA Madura Press.

Purnomo, A., \& Rosyidah, E. (2019). Kita. In Suweda Ate. Sumenep: STIEBA Madura Press.

Significados. (2018). Significado de Poesía. Retrieved June 29, 2019, from https://www.significados.com/poesia/ 